\title{
含水酸化鉄結晶表面の $\mathrm{SO}_{2}$ および $\mathrm{H}_{2} \mathrm{O}$ 吸着サイト
}

\author{
(1980 年 1 月 18 日 受理) \\ 石川達雄・井上勝也 世 $^{*}$
}

含水酸化鉄 $(\alpha-, \beta-$ および $\gamma-\mathrm{FeOOH})$ への $\mathrm{SO}_{2}$ および $\mathrm{H}_{2} \mathrm{O}$ の不可逆吸着量を $30.0^{\circ} \mathrm{C}$ で重量法 により測定した。単位表面積あたりに不可逆吸着した $\mathrm{SO}_{2}$ と $\mathrm{H}_{2} \mathrm{O}$ のモル数は等しくなった。混合が ス $\left(\mathrm{SO}_{2}-\mathrm{H}_{2} \mathrm{O}\right)$ からの不可逆吸着量は, 純 $\mathrm{SO}_{2}$ 之純 $\mathrm{H}_{2} \mathrm{O}$ からの不可逆吸着量の和に近い。先に不可 逆吸着した $\mathrm{H}_{2} \mathrm{O}$ は後から吸着する $\mathrm{SO}_{2}$ の不可逆吸着量に影響しなかった。また吸着順序をかえてる 同様であった。これらのことは, $\mathrm{SO}_{2}$ と $\mathrm{H}_{2} \mathrm{O}$ の吸着ザイは異なるが, サイト数は同じであることを 示している。 $\mathrm{FeOOH}$ 表面の構造から, $\mathrm{SO}_{2}$ 吸着サイトは表面 $\mathrm{O}^{2-}$ で, $\mathrm{H}_{2} \mathrm{O}$ 吸着サイトは表面 $\mathrm{OH}^{-}$ であると考えられ， $\mathrm{SO}_{2}$ と $\mathrm{H}_{2} \mathrm{O}$ の吸着模型を想定した。

\section{1 楮 言}

固体表面の気体分子吸着の研究に扎いては，表面積の大きい、粉 体を用いることが多い。しかし，粉体の表面構造は一般に複雑で あるため, 試料固体表面の気体分子吸着サイトについて論ずるこ とが簡単ではない。このため, 表面構造のはっきりした微細結晶 で吸着サイトを実験的倹証できる物質を研究対象として選ばな けれぱならない。含水酸化鉄類 $(\alpha-, \beta-$ および $\gamma-\mathrm{FeOOH})$ は長 さが約 $0.2 \sim 0.3 \mu$ の板状または棒状粒子として得られる。それ

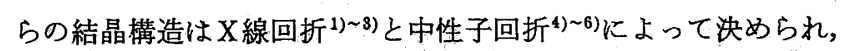
また制限視野電子回折に上れば粒子表面の $90 \%$ を占める特定の 表面 (支配表面) が存在する ${ }^{377}$ )。結晶構造から表面構造を推察す ると, 表面には $0^{2-}$ と $\mathrm{OH}^{-}$が露出し, それらの幾何学的配置 が結晶型によって異なる。この表面に構造と性質に差のある分子 を吸着させ，表面構造との関係を調べることにより，気体分子の 吸着サイトを推定することができる。 Russell らは $\alpha$ - $\mathrm{FeOOH}$ が 支配表面をもつことに注目し， $\mathrm{H}_{2} \mathrm{O}$ と $\mathrm{CO}_{2}$ の吸着状態を IR で

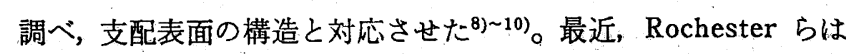

* 千葉大学理学部化学教室, 260 千葉市弥生町

1) F. J. Ewing, J. Chem. Phys., 3, 420(1935).

2) F. J. Ewing, ibid., 3, 203(1935).

3) A. L. Mackay, Mineral. Mag., 32, 545(1960).

4) J. B. Forsyth, I. G. Hedley, C. E. Johnson, J. Phys. C, 1, 179(1968).

5) A. Szytula, M. Balanda, Z. Dimitrijevic, Phys. Status Solidi A, 3, 1033(1970).

6) A. Oles, A. Szytula, A. Wanic, Phys. Status Solidi, 41, 173(1970).

7) G.W. van Oosterhout, Acta Crystallogr., 13, 932 (1960).

8) J. D. Russell, R. L. Parfitt, A.R. Fraser, V.C. Farmer, Nature, 248, 220(1974).

9) R. L. Parfitt, J. D. Russell, V.C. Farmer, J. Chem. Soc., Faraday Trans. 1, 72, 1082(1976).

10) J. D. Russell, E. Paterson, A. R. Fraser, V.C. Farmer, ibid., 71, 1623(1975).
$\alpha-\mathrm{FeOOH}$ にプロープ分子としてピリシン，醀酸，二酸化炭素， 一酸化窒素怙よびトリメチルクロロシランを吸着させ，それぞれ の吸着状態を IR で調へ, $\alpha$ - $\mathrm{FeOOH}$ の表面構造を考察した ${ }^{11212 \%}$

著者らは, 含水酸化鉄が $\mathrm{SO}_{2}$ を化学吸着する能力が高いことを 見いだして以来 ${ }^{13)}, \mathrm{SO}_{2}$ 吸着材料としての可能性を検討する目的 で，燃焼炉排ガス組成に近い混合気体からの $\mathrm{SO}_{2}$ 吸着実験を行 ない, $\mathrm{SO}_{2}$ 吸着能は共存する $\mathrm{H}_{2} \mathrm{O}$ の影響をほとんどらけないこ とを知り, $\mathrm{SO}_{2}$ と $\mathrm{H}_{2} \mathrm{O}$ は異なるサイトに吸着すると予想した ${ }^{14)}$ 。 さらに; $\mathrm{SO}_{2}$ と $\mathrm{H}_{2} \mathrm{O}$ は鉄の大気腐食において重要な役割をむ つ。 $\mathrm{SO}_{2}$ は $\mathrm{H}_{2} \mathrm{O}$ 共存下で腐食をいちじるしく促進することが知 られている(5)。鉄さびの主成分である含水酸化鉄への $\mathrm{SO}_{2}$ と $\mathrm{H}_{2} \mathrm{O}$ の吸着を調べことは, 大気腐食に拈ける $\mathrm{SO}_{2}$ と $\mathrm{H}_{2} \mathrm{O}$ の役割を 知るために必要である。

本報では，吸着気体分子として $\mathrm{SO}_{2} と \mathrm{H}_{2} \mathrm{O}$ を用い， $\alpha-, \beta-お$ よび $\gamma-\mathrm{FeOOH}$ への吸着測定を行ない; 支配表面の構造から $\mathrm{SO}_{2}$ と $\mathrm{H}_{2} \mathrm{O}$ の吸着サイトについて考察した。

\section{2 実・験}

\section{1 試: 料}

含水酸化鉄 $(\alpha-, \beta-$ および $\gamma-\mathrm{F}(\mathrm{OOH})$ は既報13)にしたがって 調製した。 $\alpha-\mathrm{FeOOH}$ は， $25^{\circ} \mathrm{C}$ 以下で硫酸鉄(III)を溶かした 0.6 $\mathrm{mol} / l$ 溶液に $1 \mathrm{~mol} / l$ 水酸化ナトリウム溶液を, $25^{\circ} \mathrm{C}$ 以下にたも ちながら加えて $\mathrm{pH} 13.6$ Kし，50C で 30 時間たもって調製し た。 $\beta-\mathrm{FeOOH}$ は, $0.1 \mathrm{~mol} / l$ 塩化鉄 (III) 溶液 $500 \mathrm{~mol} / l$ に尿素 $30 \mathrm{~g}$ を加光， $1^{\circ} \mathrm{C} / \mathrm{min}$ で $95^{\circ} \mathrm{C}$ まで昇温し，95 99 $\mathrm{C}$ で 5 時間加熱 して調製した。 $r-\mathrm{FeOOH}$ は， $0.2 \mathrm{~mol} / l$ 塩化鉄(II)溶液に $2 \mathrm{~mol} / l$ のウロトロピン $\left(\left(\mathrm{CH}_{2}\right)_{8} \mathrm{~N}_{4}\right)$ 溶液を加えて水酸化物をつくり，塩 酸酸性で $1.0 \mathrm{~mol} / l$ 亜硝酸ナトリウム溶液を加文, $60^{\circ} \mathrm{C}$ で 45 分

11) C. H. Rochester, S. A. Topham, J. Chem. Soc., Faraday Trans: 1, 75, 591(1979).

12) C. H. Rochester, S. A. Topham, ibid., 75, 872(1979).

13）石川達雄, 井上勝也, 日化, 91, 935(1970).

14）石川達雄, 井上勝也, 日化，1979，697.

15）たとえば，久松敬弘，“鉄鋼席食科学”，朝倉書店（1972）第 3 章. 
Table 1 Monolayer adsorption capacity $\left(A_{\mathrm{m}}\right)$ and amount of irreversible adsorption $\left(A_{1}\right)$ of $\mathrm{SO}_{2}$ and $\mathrm{H}_{2} \mathrm{O}$

\begin{tabular}{|c|c|c|c|c|c|c|c|}
\hline \multirow{2}{*}{ Sample } & \multirow{2}{*}{$\begin{array}{l}\text { Surface area } \\
\left(\mathrm{m}^{2} / \mathrm{g}\right)\end{array}$} & \multicolumn{2}{|c|}{$\begin{array}{l}\mathrm{SO}_{2} \text { adsorption } \\
\left(\mathrm{mg} / \mathrm{m}^{2}\right)\end{array}$} & \multicolumn{2}{|c|}{$\begin{array}{c}\mathrm{H}_{2} \mathrm{O} \text { adsorption } \\
\left(\mathrm{mg} / \mathrm{m}^{2}\right)\end{array}$} & \multicolumn{2}{|c|}{$\begin{array}{c}\text { Mole ratio of adsorbed } \\
\mathrm{SO}_{2} \text { and } \mathrm{H}_{2} \mathrm{O}\end{array}$} \\
\hline & & $A_{\mathrm{m}}$ & $A_{1}$ & $A_{\mathrm{m}}$ & $A_{1}$ & $\frac{A_{\mathrm{m}}\left(\mathrm{H}_{2} \mathrm{O}\right)}{A_{\mathrm{m}}\left(\mathrm{SO}_{2}\right)}$ & $\frac{A_{1}\left(\mathrm{H}_{2} \mathrm{O}\right)}{A_{1}\left(\mathrm{SO}_{2}\right)}$ \\
\hline $\boldsymbol{\alpha}-\mathrm{FeOOH}$ & 74 & 0.542 & $0: 256$ & $0: 285$ & 0.082 & 1.9 & 1.1 \\
\hline$\beta-\mathrm{FeOOH}$ & 25 & 0.548 & 0.398 & 0.446 & 0.278 & $2.9[1.8]$ & $2.5[1.0]$ \\
\hline$\gamma-\mathrm{FeOOH}$ & 114 & 0.535 & 0.263 & 0.335 & 0.095 & 2.2 & 1.3 \\
\hline
\end{tabular}

Values in the brackets were calculated by subtracting the amount of $\mathrm{H}_{2} \mathrm{O}$ in the tunnels $\beta-\mathrm{FeOOH}$ from $A_{\mathrm{m}}$ or $A_{1}$.

間たもって調製した。いずれの場合も，得られた沈殿を沪別し， 蒸留水で $\mathrm{SO}_{4}^{2-}$ または $\mathrm{Cl}^{-}$が検出されなくなるまで洗浄した。 試料はX線回折 ( $\left.\mathrm{Fe} K_{\alpha}, 10 \mathrm{~mA}, 30 \mathrm{kV}\right)$ で純粋なるのであること を確認した。比表面積は液体窒素温度で $\mathrm{N}_{2}$ 吸着による BET 法 で求めた。

\section{2 実験方法}

$\mathrm{SO}_{2}$ および $\mathrm{H}_{2} \mathrm{O}$ の吸着量は石英スプリング (感度, $214 \mathrm{~mm} /$ g）を用いた重量法により，30.0 $\mathrm{C}$ で測定した。吸着の前に試料 を $105 \sim 110^{\circ} \mathrm{C}, 10^{-5}$ Torr で 14 時間処理した。 $\mathrm{SO}_{2}$ は分別蒸留 をくり返して精製した。 $\mathrm{H}_{2} \mathrm{O}$ は塩化バリウム $\left(\mathrm{BaCl}_{2} \cdot 2 \mathrm{H}_{2} \mathrm{O}\right)$ の 結晶水を加熱して発生させた。吸着等温線から BET 式によって 単分子層吸着量を計算した。等温線を測定したのちたたらに脱着 を行ない, $30.0^{\circ} \mathrm{C}, 10^{-5}$ Torr で 24 時間排気し, 残留吸着量を 不可逆吸着量とした。

\section{3 結果および考察}

\section{1 $\mathrm{SO}_{2}$ と $\mathrm{H}_{2} \mathrm{O}$ の吸着量の比較}

3.1 .1 単分子首吸着量: $\mathrm{SO}_{2}$ および $\mathrm{H}_{2} \mathrm{O}$ の吸着等温線に $\mathrm{BET}$ 式を適用して算出した単分子層吸着量を， $\mathrm{N}_{2}$ 吸着による比表面 積を使って面積あたりの吸着量（ $A_{\mathrm{m}}$ ) にすると表 1 のようにな る。 $\mathrm{SO}_{2}$ 吸着での $A_{\mathrm{m}}$ の值は結晶型によらずほぼ一定であるが, $\mathrm{H}_{2} \mathrm{O}$ 吸着では $\alpha-, \beta-$ および $\gamma-\mathrm{FeOOH}$ において差があり $\beta$ $\mathrm{FeOOH}$ でもっとも大きなった。 $\beta-\mathrm{FeOOH}$ 結晶中には，入口 の大きさが $2.54 \AA$ のトンネルがある ${ }^{16)}$ 。このには $\mathrm{H}_{2} \mathrm{O}$ 分子 (值径 $2.5 \AA$ ) は入れるが， $\mathrm{N}_{2}$ 分子は入れないため， $\mathrm{N}_{2}$ 吸着に よる比表面積を使った面積あたりの $\mathrm{H}_{2} \mathrm{O}$ 単分子凮吸着量 $\left(A_{\mathrm{m}}\right)$ の值は大きくなる。

他方, $\mathrm{SO}_{2}$ (值径 4.0 $\mathrm{A}$ ) はトンネル内に吸着されず外部表面 のみに吸着すると予想される。Emmett と Brunauer の方法 ${ }^{17)}$ で求めた $\mathrm{SO}_{2}$ の分子占有面積 $\left(19.2 \AA^{2}\right)$ と試料 $1 \mathrm{~g}$ あたりの $\mathrm{SO}_{2}$ 単分子層吸着量から $\beta-\mathrm{FeOOH}$ の比表面積を求めると $25 \mathrm{~m}^{2} / \mathrm{g}$ と なり， $\mathrm{N}_{2}$ 吸着で求めた比表面積 $\left(25 \mathrm{~m}^{2} / \mathrm{g}\right)$ と一致する。このこ とから $\mathrm{SO}_{2}$ は $\mathrm{N}_{2}$ と同様に外部表面に吸着することがわかる。 $\mathrm{SO}_{2}$ および $\mathrm{H}_{2} \mathrm{O}$ 吸着での $A_{\mathrm{m}}$ を面積あたりのモル数にしたもの をそれぞれ $A_{\mathrm{m}}\left(\mathrm{SO}_{2}\right)$ および $A_{\mathrm{m}}\left(\mathrm{H}_{2} \mathrm{O}\right)$ とし, それらの比 $A_{\mathrm{m}}$ $\left(\mathrm{H}_{2} \mathrm{O}\right) / A_{\mathrm{m}}\left(\mathrm{SO}_{2}\right)$ の值を表 1 に示した。

$\beta-\mathrm{FeOOH}$ で $A_{\mathrm{m}}\left(\mathrm{H}_{2} \mathrm{O}\right) / A_{\mathrm{m}}\left(\mathrm{SO}_{2}\right)$ の值が大きいのは, $\mathrm{H}_{2} \mathrm{O}$ はト ンネル内に吸着するが $\mathrm{SO}_{2}$ は吸着しないためである。 $\beta-\mathrm{FeOOH}$ の外部表面に吸着している $\mathrm{H}_{2} \mathrm{O}$ 量を, $\mathrm{N}_{2}$ 吸着による比表面積と $\mathrm{H}_{2} \mathrm{O}$ 分子の占有面積 $\left(10.8 \AA^{2}\right)^{18)}$ を使って算出したところ 0.277

16) T. Ishikawa, K. Inouye, Bull. Chem. Soc. Jpn., 46, 2665(1973).

17) P. H. Emmett, S. Brunauer, J. Am. Chem. Soc., 59, 1553(1937). $\mathrm{mg} / \mathrm{m}^{2}$ そなった。この值を使った $\beta-\mathrm{FeOOH}$ の $A_{\mathrm{m}}\left(\mathrm{H}_{2} \mathrm{O}\right) / A_{\mathrm{m}}$ $\left(\mathrm{SO}_{2}\right)$ は 1.8 になる（表 1 )。 $\mathrm{SO}_{2}$ 分子の占有面積 $\left(19.2 \AA^{2}\right)$ と $\mathrm{H}_{2} \mathrm{O}$ 分子の占有面積 $\left(10.8 \AA^{2}\right)$ の比は 1.8 であり, $\alpha$-および $\beta-\mathrm{FeOOH}$ の $A_{\mathrm{m}}\left(\mathrm{H}_{2} \mathrm{O}\right) / A_{\mathrm{m}}\left(\mathrm{SO}_{2}\right)$ の值にほぼ等しい。 $\gamma-\mathrm{FeOOH}$ では $A_{\mathrm{m}}\left(\mathrm{H}_{2} \mathrm{O}\right) / A_{\mathrm{m}}\left(\mathrm{SO}_{2}\right)$ の値は 2.2 で大きい。 $r-\mathrm{FeOOH}$ 表面 の $\mathrm{OH}^{-}$は脱離しや寸く ${ }^{19)}$ ，本実験の前処理で $\mathrm{OH}^{-}$の一部が脱 離して欠陷が生成し， $\mathrm{H}_{2} \mathrm{O}$ の吸着サイトになっているものと思わ れる。

3.1 .2 不可逆吸着量: 脱着等温線は吸着量が単分子層吸着量 に達するガス王付近までは吸着等温線と一致するが，それ以下の 圧つまり単分子層吸着が起こっているところでは一致しない。さ らにガス压を下げ， $10^{-5}$ Torr で排気しても完全には脱着せず， 不可逆吸着が起こっている。そこで, 吸着温度と同じ $30.0^{\circ} \mathrm{C} て ゙$, $1_{0^{-5}}$ Torr 下で 24 時間排気 しても脱着しない $\mathrm{SO}_{2} お$ よび $\mathrm{H}_{2} \mathrm{O}$ 量を不可逆吸着量とした。不可逆吸着した $\mathrm{SO}_{2}$ はつぎの理由に より化学吸着しているものと思われる。 $\mathrm{SO}_{2}$ を吸着した試料は $\mathrm{SO}_{4}^{2-}$ の IR 吸収帯を示し, 吸着 $\mathrm{SO}_{2}$ は $\mathrm{O}_{2}$ を含まない水によっ て $\mathrm{SO}_{4}^{\prime 2}$ - として抽出される ${ }^{13)}$ 。吸着した $\mathrm{SO}_{2}$ は加熱すると $200^{\circ} \mathrm{C}$ 以上で $\mathrm{SO}_{3}$ として脱離する ${ }^{20)}$ 。また，含水酸化鉄の電気伝導度 は $\mathrm{SO}_{2}$ 吸着によりいちじるしく低下する21。

他方, $\mathrm{H}_{2} \mathrm{O}$ 吸着によって, 含水酸化鉄の電気伝導度が増加する ことや22)，誘電率測定により表面に強く束镈されて誘電率への寄 与が小さい $\mathrm{H}_{2} \mathrm{O}$ 分子があることが知られている ${ }^{28)}$ 。不可逆吸着 $\mathrm{H}_{2} \mathrm{O}$ は物理吸着よりも強く吸着していると考竞られているが，化 学吸着しているとは現在のところいえない。

$\mathrm{SO}_{2}$ および $\mathrm{H}_{2} \mathrm{O}$ の面積あたりの不可逆吸着量 $\left(A_{1}\right)$ は表 1 の よらに $\alpha-\mathrm{FeOOH}$ と $\gamma-\mathrm{FeOOH}$ の值は大差がないが，それらに くらぺて $\beta-\mathrm{FeOOH}$ で大きい。 $\beta-\mathrm{FeOOH}$ で $\mathrm{H}_{2} \mathrm{O}$ の $A_{1}$ 值が大 きいのは, $\beta-\mathrm{FeOOH}$ のトンネル内に吸着した $\mathrm{H}_{2} \mathrm{O}$ が脱着時の 排気では脱離しないためと思われる。 $\mathrm{SO}_{2}$ と $\mathrm{H}_{2} \mathrm{O}$ の不可逆吸着 量を面積あたりのモル数で表わした値をそれぞれ $A_{1}\left(\mathrm{SO}_{2}\right)$ と $A_{1}$ $\left(\mathrm{H}_{2} \mathrm{O}\right)$ とする。 $A_{1}\left(\mathrm{H}_{2} \mathrm{O}\right) / A_{\mathrm{i}}\left(\mathrm{SO}_{2}\right)$ の值は表 1 のように, $\alpha$ $\mathrm{FeOOH}$ と $\gamma-\mathrm{FeOOH}$ では 1 に近くなり, $\beta-\mathrm{FeOOH} て ゙ は 2.5$ と なる。 $\beta-\mathrm{FeOOH}$ のトンネル内に吸着した $\mathrm{H}_{2} \mathrm{O}$ 量を, $\mathrm{H}_{2} \mathrm{O}$ の $A_{\mathrm{m}}$ 値 $\left(0.446 \mathrm{mg} / \mathrm{m}^{2}\right)$ から前節で述べた外部表面に吸着した $\mathrm{H}_{2} \mathrm{O}$ 量

18) H. K. Livingston, J. Colloid Sci., 4, 447(1949).

19) K. Kaneko, K. Inouye, Bull. Chem. Soc. Jpn., 49, 3689(1976).

20）石川達雄, 井上勝也, 第 26 回コロイドおよび界面化学討 論会講演要旨集, p.150 (1973).

21）金子克美, 石川達雄, 井上勝也, 日化, 1977, 162.

22) K. Kaneko, K. Inouye, Bull. Chem. Soc. Jpn., 52, 315(1979).

23) K. Kaneko, M. Serizawa, T. Ishikawa, K. Inouye, ibid., 48, 1764(1975). 
Table 2 Amount of the irreversible adsorption of $\mathrm{SO}_{2}$ and $\mathrm{H}_{2} \mathrm{O}$ from the mixed gas $\left(\mathrm{SO}_{2}-\mathrm{H}_{2} \mathrm{O}\right)\left(\mathrm{A}_{1}\left(\mathrm{SO}_{2}-\right.\right.$ $\left.\mathrm{H}_{2} \mathrm{O}\right)$ ) and the sum of amounts of irreversible adsorption of the pure gases $\left(A_{1}\left(\mathrm{SO}_{2}\right)+A_{1}\left(\mathrm{H}_{2} \mathrm{O}\right)\right)$

\begin{tabular}{lcc} 
Sample & $\begin{array}{c}A_{1}\left(\mathrm{SO}_{2}-\mathrm{H}_{2} \mathrm{O}\right) \\
\left(\mathrm{mg} / \mathrm{m}^{2}\right)\end{array}$ & $\begin{array}{c}A_{1}\left(\mathrm{SO}_{2}\right)+A_{1}\left(\mathrm{H}_{2} \mathrm{O}\right) \\
\left(\mathrm{mg} / \mathrm{m}^{2}\right)\end{array}$ \\
\hline$\alpha-\mathrm{FeOOH}$ & $0.348 \pm 0.017$ & $0.338 \pm 0.007$ \\
$\beta-\mathrm{FeOOH}$ & $0.775 \pm 0.039$ & $0.676 \pm 0.011$ \\
$\gamma-\mathrm{FeOOH}$ & $0.245 \pm 0.012$ & $0.258 \pm 0.008$
\end{tabular}

Table 3 Effect of pre-adsorbed $\mathrm{H}_{2} \mathrm{O}$ on the irreversible adsorption of $\mathrm{SO}_{2}$

\begin{tabular}{ccc} 
Sample & $\begin{array}{c}A_{1}\left(\mathrm{SO}_{2}\right) \text { for the surface } \\
\text { pre-adsorbed with } \mathrm{H}_{2} \mathrm{O} \\
\left(\mathrm{mg} / \mathrm{m}^{2}\right)\end{array}$ & $\begin{array}{c}A_{1}\left(\mathrm{SO}_{2}\right) \text { for the } \\
\text { bare surface } \\
\left(\mathrm{mg} / \mathrm{m}^{2}\right)\end{array}$ \\
\hline$\alpha-\mathrm{FeOOH}$ & $0.250 \pm 0.013$ & $0.256 \pm 0.003$ \\
$\beta-\mathrm{FeOOH}$ & $0.386 \pm 0.019$ & $0.398 \pm 0.009$ \\
$\gamma-\mathrm{FeOOH}$ & $0.279 \pm 0.014$ & $0.263 \pm 0.003$
\end{tabular}

Table 4. Effect of pre-adsorbed $\mathrm{SO}_{2}$ on the irreversible adsorption of $\mathrm{H}_{2} \mathrm{O}$

\begin{tabular}{ccc} 
Sample & $\begin{array}{c}A_{1}\left(\mathrm{H}_{2} \mathrm{O}\right) \text { for the surface } \\
\text { pre-adsorbed with } \mathrm{H}_{2} \mathrm{O} \\
\left(\mathrm{mg} / \mathrm{m}^{2}\right)\end{array}$ & $\begin{array}{c}A_{1}\left(\mathrm{H}_{2} \mathrm{O}\right) \text { for the } \\
\text { bare surface } \\
\left(\mathrm{mg} / \mathrm{m}^{2}\right)\end{array}$ \\
\hline$\alpha-\mathrm{FeOOH}$ & $0.076 \pm 0.004$ & $0.082 \pm 0.004$ \\
$\beta-\mathrm{FeOOH}$ & $0.130 \pm 0.007$ & $0.278 \pm 0.004$ \\
$\gamma-\mathrm{FeOOH}$ & $0.084 \pm 0.004$ & $0.095 \pm 0.005$
\end{tabular}

(0. $\left.277 \mathrm{mg} / \mathrm{m}^{2}\right)$ を差し引いて求めると $0.169 \mathrm{mg} / \mathrm{m}^{2}$ になる。こ の值を表 1 の $A_{\mathrm{i}}\left(\mathrm{H}_{2} \mathrm{O}\right)$ の值から差し引いて $A_{\mathrm{i}}\left(\mathrm{H}_{2} \mathrm{O}\right) / A_{\mathrm{i}}\left(\mathrm{SO}_{2}\right)$ を 求めると1.0となる。すべての結晶型について $A_{\mathrm{i}}\left(\mathrm{H}_{2} \mathrm{O}\right) / A_{1}\left(\mathrm{SO}_{2}\right)$ が 1 に近いことは, $\mathrm{SO}_{2}$ と $\mathrm{H}_{2} \mathrm{O}$ の吸着分子数が等しく, $\mathrm{FeOOH}$ 表面でのそれぞれの分子に対する吸着サイト数が等しいことを示 している。

\section{2 混合ガス $\left(\mathrm{SO}_{2}-\mathrm{H}_{2} \mathrm{O}\right)$ の吸着}

$\mathrm{SO}_{2}$ と $\mathrm{H}_{2} \mathrm{O}$ をそれぞれ 360 Torr と 12 Torr ずつ混合したガ スを吸着させ，純粋ガスの吸着と同様にして不可逆吸着量を测定 した。これらのガス圧はおの括のの純粋ガスで単分子層を形成す るに十分なガス压である。表 2 のように純粋ガスの $A_{1}$ の和と混 合ガスの $A_{\mathrm{i}}$ 值は $\beta-\mathrm{FeOOH}$ 以外はほぼ等しい。この結果から, $\mathrm{SO}_{2}$ と $\mathrm{H}_{2} \mathrm{O}$ は同一吸着サイトに競争吸着せず，たがいに異なる

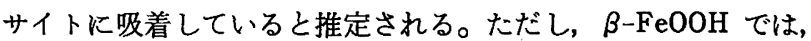
混合ガスからの吸着量の方が多いが，これについては 3.4 に述べ る。

\section{3 気体分子を不可逆吸着した試料への吸着}

$\mathrm{SO}_{2}$ と $\mathrm{H}_{2} \mathrm{O}$ の吸着サイトが異なることを確かめる目的で，一 方の気体を先に不可逆吸着させた試料へ他方の気体を後から吸着 させて，不可逆吸着量を測定した。

$\mathrm{H}_{2} \mathrm{O}$ を不可这吸着した試料の $\mathrm{SO}_{2}$ 不可逆吸着量は, $\mathrm{H}_{2} \mathrm{O}$ を吸 着していない表面への不可逆吸着量 $\left(A_{1}\right)$ とほぼ等しい（表 3 )。 すなわち，不可逆吸着した $\mathrm{H}_{2} \mathrm{O}$ は $\mathrm{SO}_{2}$ の吸着に影響せず $\mathrm{SO}_{2}$ は $\mathrm{H}_{2} \mathrm{O}$ 吸着サイトと異なるサイトに吸着することがわかる。つ ぎに逆に $\mathrm{SO}_{2}$ を不可逆吸着した試料に $\mathrm{H}_{2} \mathrm{O}$ を後から吸着させた ときの不可逆吸着量は， $\beta-\mathrm{FeOOH}$ では $\mathrm{SO}_{2}$ を吸着していない表 面での不可逆吸着量 $\left(A_{1}\right)$ の半分以下になる（表 4 )。 $\beta-\mathrm{FeOOH}$
Table 5 Number of adsorbed $\mathrm{SO}_{2}$ and $\mathrm{H}_{2} \mathrm{O}$ molecules, surface $\mathrm{O}^{2-}$ ions, and surface $\mathrm{OH}^{-}$ions per a surface unit cell

\begin{tabular}{lllcc} 
Sample & $\begin{array}{c}\text { Adsorbed } \\
\mathrm{SO}_{2}\end{array}$ & $\begin{array}{c}\text { Adsorbed } \\
\mathrm{H}_{2} \mathrm{O}\end{array}$ & $\begin{array}{c}\text { Surface } \\
\mathrm{O}^{2-}\end{array}$ & $\begin{array}{c}\text { Surface } \\
\mathrm{OH}^{-}\end{array}$ \\
\hline$\alpha-\mathrm{FeOOH}$ & $0.74[1]$ & $0.83[1]$ & 2 & 2 \\
$\beta-\mathrm{FeOOH}$ & $1.19[1]$ & $1.15[1]$ & 2 & 2 \\
$\gamma-\mathrm{FeOOH}$ & $0.29[1 / 4]$ & $0.38[1 / 4]$ & 1 & .1
\end{tabular}

Values in the brackets were estimated from the adsorption models in Figs. 1 through 3.

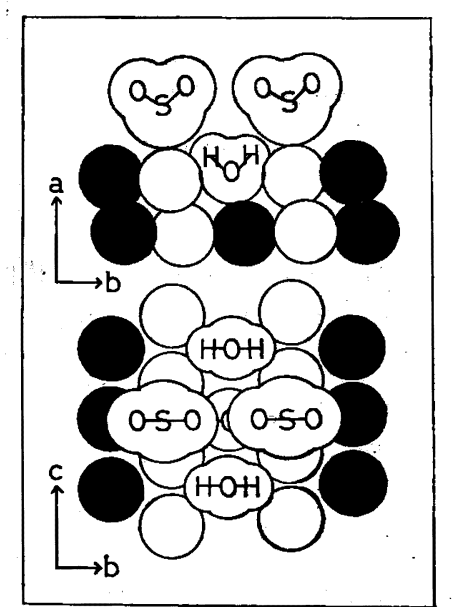

Fig. 1 Adsorption models of $\mathrm{SO}_{2}$ and $\mathrm{H}_{2} \mathrm{O}$ on $\alpha-\mathrm{FeOOH}$ $\mathrm{O}: \mathrm{O}^{2-}, \mathrm{O}: \mathrm{OH}^{-}$

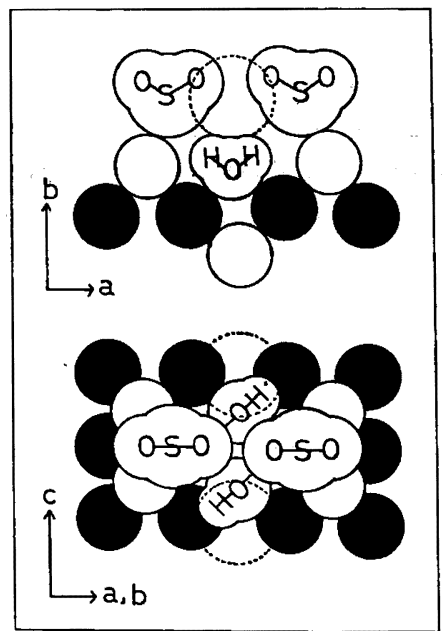

Fig. 2 Adsorption models of $\mathrm{SO}_{2}$ and $\mathrm{H}_{2} \mathrm{O}$ on $\beta-\mathrm{FeOOH}$

$$
\mathrm{O}: \mathrm{O}^{2-}, \mathrm{O}: \mathrm{OH}^{-}
$$

へ先に吸着した $\mathrm{SO}_{2}$ はトンネルの入口をふさぎ後から吸着する $\mathrm{H}_{2} \mathrm{O}$ のトンネル内吸着を妨害するため, $\mathrm{H}_{2} \mathrm{O}$ 不可逆吸着量が減 少するものと思われる。

先に吸着した $\mathrm{SO}_{2}$ による $\mathrm{H}_{2} \mathrm{O}$ 不可逆吸着量の减少は, 表 4 よ り $0.148 \mathrm{mg} / \mathrm{m}^{2}$ で, トンネル内吸着量の推定值 $\left(0.169 \mathrm{mg} / \mathrm{m}^{2}\right)$ にかなり近い。このことも $\mathrm{SO}_{2}$ によって $\mathrm{H}_{2} \mathrm{O}$ のトンネル内吸着 が妨害されているとする考えを支持している。 $\beta-\mathrm{FeOOH}$ 以外の 試料でも $\mathrm{H}_{2} \mathrm{O}$ 不可逆吸着量はあらかじめ吸着している $\mathrm{SO}_{2}^{\circ} に よ$ 


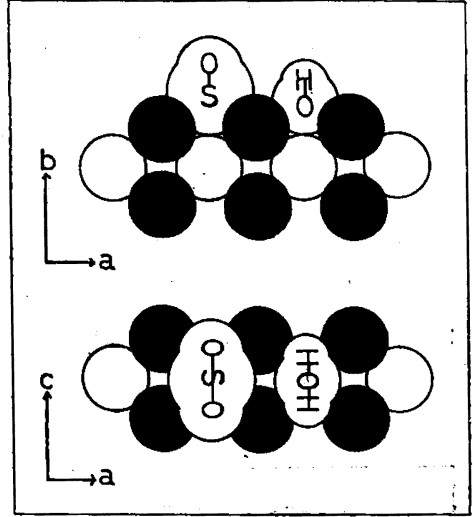

Fig. 3 Adsorption models of $\mathrm{SO}_{2}$ and $\mathrm{H}_{2} \mathrm{O}$ on $\gamma-\mathrm{FeOOH}$ $\mathrm{O}: \mathrm{O}^{2-}, \mathrm{O}: \mathrm{OH}^{-}$

ってねずかに減少する。 $\mathrm{SO}_{2}$ は $\mathrm{H}_{2} \mathrm{O}$ よりも反応性にとむため, $\mathrm{H}_{2} \mathrm{O}$ の吸着サイトの一部に $\mathrm{SO}_{2}$ が吸着すると考えられるが，大 部分のサイトは $\mathrm{SO}_{2}$ の影響をらけず， $\mathrm{H}_{2} \mathrm{O}$ は $\mathrm{SO}_{2}$ とは異なる サイトに吸着するといえよう。

\section{$3.4 \mathrm{SO}_{2}$ およひ $\mathrm{H}_{2} \mathrm{O}$ の吸着模型}

含水酸化鉄の支配表面济， $\alpha \div \mathrm{FeOOH}$ では b-c 面, $\beta-\mathrm{FeOOH}$ では a-c または b-c 面, $-\mathrm{F}<\mathrm{FeOH}$ 大゙は、-c 面からなる3)。 その構造を図 $1 \stackrel{\sim}{\sim} 3$ に示した。いずれす $0^{2-}$ と $\mathrm{OH}^{-}$が表面に露 出して扣り， $\mathrm{SO}_{2}$ と $\mathrm{H}_{2} \mathrm{O}$ の吸着サイトとなる。 $\mathrm{SO}_{2}$ の吸着サイ トとしては表面の $\mathrm{O}^{2-}$ が考えられる。また $\mathrm{H}_{2} \mathrm{O}$ の吸着サイト は, $\mathrm{SO}_{2}$ と異なることから，表面の $\mathrm{OH}^{-}$であると思われる。眓 1 3 の表面構造から, 吸着サイトとなりらる $\mathrm{O}^{2-}$ と $\mathrm{OH}^{-}$の数 は単位格子あたり $\alpha-\mathrm{FeOOH}$ と $\beta-\mathrm{FeOOH}$ でそれぞれ 2, $\gamma$ $\mathrm{FeOOH}$ ではそれぞれ 1 であり， $\mathrm{O}^{2-}$ と $\mathrm{OH}^{-}$数が等しい(表 5 )。 このことは $\mathrm{SO}_{2}$ と $\mathrm{H}_{2} \mathrm{O}$ の吸着分子数が同じであることと一致す る。な技， $\alpha-\mathrm{FeOOH}$ と $\beta-\mathrm{FeOOH}$ の表面にあるくぼみの奥に O2- があるが，気体分子が結合するのは無理で，吸着サイトとな り得ないと考えた。

$\mathrm{SO}_{2}$ および $\mathrm{H}_{2} \mathrm{O}$ 分子の大きさと形を考虑して, 各 $\mathrm{FeOOH}$ 上

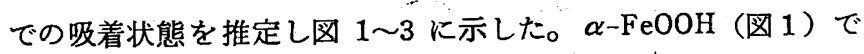
は, $\mathrm{SO}_{2}$ は二つの $\mathrm{O}^{2-}$ と $\mathrm{H}_{2} \mathrm{O}$ はくぼんたところにある一つの $\mathrm{OH}^{-}$と結合する。表面に突きでた $\mathrm{OH}^{-}$にも $\mathrm{H}_{2} \mathrm{O}$ は吸着するが
排気炕よって脱着し〈ぼみに入った $\mathrm{H}_{2} \mathrm{O}$ のみが不可逆吸着す ると考えた。したがって，見かけ上 $\mathrm{SO}_{2}$ は二つの $0^{2-}$ と結合し， $\mathrm{H}_{2} \mathrm{O}$ は二つの $\mathrm{OH}^{-}$を占めることになる。 は, 突きでた $\mathrm{O}^{2-}$ 二つに $\mathrm{SO}_{2}$ が 1 分子吸着し〈ぼにある $\mathrm{OH}^{-}$二つに 1 分子の $\mathrm{H}_{2} \mathrm{O}$ が吸着する。表 2 で $\beta-\mathrm{FeOOH}$ の混 合ガスの不可逆吸着量は純粋がスの不可逆吸着量の和よりもかな り多い。図 2 の吸着モデルで, くほみの部分に $\mathrm{SO}_{2}$ と $\mathrm{H}_{2} \mathrm{O}$ に囲 まれた空間（図2の点線で示した部分）があり， $\mathrm{H}_{2} \mathrm{O}$ 分子はその 中に入りらる。混合ガス吸着ではその空間に $\mathrm{H}_{2} \mathrm{O}$ が入り, 脱着 時の排気では脱離しないものと思われる。 $\gamma-\mathrm{FeOOH}$ の表面（図 3）は他の結晶型とは異なり， $\mathrm{OH}^{-}$で肉一におおわれている。 08- はややひっこんたところにある。金子らによれば,この $0^{2-}$ の残余静電原子価は 0 で $\mathrm{SO}_{2}$ の吸着サイトにならず, $\mathrm{SO}_{2}$ は $\mathrm{OH}^{-}$の酸素原子に結合すると考えた ${ }^{21)}$ 。

本実験の結果すなわち $\mathrm{SO}_{2}$ と $\mathrm{H}_{2} \mathrm{O}$ はおたがいの吸着に影響し ないこと，吸着分子数の比 $A_{1}\left(\mathrm{H}_{2} \mathrm{O}\right) / A_{1}\left(\mathrm{SO}_{2}\right)$ が 1 であることお よび単位格子あたり約 $1 / 4$ 分子ずつ吸着することなどから，図 3 のような吸着模型が妥当であろら。 $\mathrm{SO}_{2}$ と $\mathrm{H}_{2} \mathrm{O}$ は四つの $\mathrm{OH}^{-}$ を占有して吸着し, $\mathrm{SO}_{2}$ 吸着サイト間に $\mathrm{H}_{2} \mathrm{O}$ が吸着するため, おたがいの吸着には影響しない。また， $r-\mathrm{FeOOH}$ 上への NO 分 子の吸着においても，NO が四つの $\mathrm{OH}^{-}$を占めて吸着するとい ら結果が得られている ${ }^{24)}$

以上のような吸着状態をとるときの吸着量と実測吸着量を表 5 で比較した。両者はあまりよく一致していない。この不一致は, 支配表面のみを使って吸着模型を考えたこと， $\mathrm{FeOOH}$ 粒子はい くつかの結晶子からなり結晶子間のみだれた部分や前処理のとき にできた久陷などを考感していないことなどによるものである。

\section{4 結 論}

$\mathrm{SO}_{2}$ と $\mathrm{H}_{2} \mathrm{O}$ は $\mathrm{FeOOH}$ 上で異なるサイトに吸着し，そのサイ 卜数は同じである。支配表面の構造を結晶学的構造から決めて吸 着モデルを想定した。 $\mathrm{FeOOH}$ 表面は理想表面に近いことがわか つだ。

本研究の研究費の一部は, 文部省科学研究費補助金（環境科学 特別研究 R $\mathrm{R}$ 32，403034）によったことを記して，謝意を表わす。

24）. 服部高明, 金子克美, 石川達雄, 井上勝也, 日化, 1979, 423. 
Adsorptive Sites for Sulfur Dioxide and Water on Iron Hydroxide Oxides

\author{
Tatsuo Ishixawa and Katsuya Inouye \\ Department of Chemistry, Faculty of Science, Chiba University; \\ Yayoi-cho, Chiba-shi 260 Japan
}

The adsorption isotherms of $\mathrm{SO}_{2}$ and $\mathrm{H}_{2} \mathrm{O}$ on iron hydroxide oxides $(\alpha-, \beta-$, and $\gamma+\mathrm{FeOOH})$ were determined gravimetrically at $30.0^{\circ} \mathrm{C}$ and the irreversible adsorption was estimated by evacuating the sample at $10^{-5}$ Torr for $24 \mathrm{~h}$ at the same temperature. The mole number of chemisorbed $\mathrm{SO}_{2}$ calculated as that per unit surface area of the oxide was nearly equal to the value of $\mathrm{H}_{2} \mathrm{O}$ which is adsorbed irreversibly (Table 1), showing that the number of adsorptive sites for $\mathrm{SO}_{2}$ is similar to that for $\mathrm{H}_{2} \mathrm{O}$. The amount of irreversible adsorption of $\mathrm{SO}_{2}$ and $\mathrm{H}_{2} \mathrm{O}$ from the mixture of $\mathrm{SO}_{2}$ and $\mathrm{H}_{2} \mathrm{O}$ was close to the sum of amounts of irreversible adsorption from each of the pure gases (Table 2). The $\mathrm{SO}_{2}$ pre-adsorbed on the $\mathrm{FeOOH}$ surfaces did not alter the amount of irreversible adsorption of $\mathrm{H}_{2} \mathrm{O}$, and also the pre-adsorbed $\mathrm{H}_{2} \mathrm{O}$ did not influence the irreversible adsorption of $\mathrm{SO}_{2}$ (Tables 3 and 4). It has been suggested that $\mathrm{SO}_{2}$ and $\mathrm{H}_{2} \mathrm{O}$ are adsorbed at different sites on the surfaces, presumably on the surface ions $\mathrm{O}^{2-}$ and $\mathrm{OH}^{-}$respectively. Figs. 1,2 , and 3 give the structural models showing the probable surface sites attached with $\mathrm{SO}_{2}$ and $\mathrm{H}_{2} \mathrm{O}$ molecules. 